\title{
HAK MENDAPATKAN PENDIDIKAN TINJAUAN EPISTIMOLOGI DAN AKSIOLOGI FILSAFAT PENDIDIKAN ISLAM
}

\author{
Samsul Hadi \\ STIT Palapa Nusantara Lombok Nusa Tenggara Barat \\ irsyadsamsul@gmail.com
}

\begin{abstract}
Education as one of the key progress and development of a country, Therefore, the right to get education for the community and citizens, of course now must be acceptable for all layers and the community. This review, will speak on the "Right to Education derived from epistemology and axiology" or from where and for whom this educational policy was made. Furthermore, this study speaks of several important points such as Education as a Nation character, an epistemological and axiological review of the right to education, the right of citizens to receive education and the obligations of government / State to organize and ensure education. In this article, the author uses the library research method to understand and find answers to some of the issues related to the right to education.
\end{abstract}

Keyword: Right to education, Islamic education philosophy

\begin{abstract}
Abstrak: Pendidikan sebagai salah satu kunci kemajuan dan berkembangan suatu negara, Oleh sebab itu, hak mendapatkan pendidikan bagi masyarakat dan warga negara, tentu kini sudah harus dapat diterima bagi seluruh lapisan dan kalangan masyarakat. Kajian ini, akan berbicara mengenai "Hak mendapatkan Pendidikan ditinjau dari epistemologi dan aksiologi" atau dari mana dan untuk siapa kebijakan pendidikan ini dibuat. Lebih jauh lagi, kajian ini berbicara mengenai beberapa poin-poin penting seperti, Pendidikan sebagai karakter Bangsa, tinjauan epistemologi dan aksiologi tentang hak mendapatkan pendidikan, hak warga negara mendapatkan pendidikan dan kewajiban pemerintah/Negara menyelenggarakan dan menjamin pendidikan. Dalam artikel ini, penulis menggunakan metode kepustakaan (library research method) untuk memahami dan menemukan jawaban dari beberapa persoalan-persoalan yang berkaitan dengan hak mendapatkan pendidikan.
\end{abstract}

Kata kunci: Hak mendapatkan pendidikan, epistemologi, aksiologi. 


\section{Pendahuluan}

Filsafat ilmu mulai banyak dibicarakan orang pada awal abad ke 20, francis Bacon merupakan orang pertama peletak dasar filsafat ilmu dengan metode induksi yang dipublikasikannya pada Abad ke 19. Ada yang menyatakan bahwa perhatian besar terhadap peran dan fungsi filsafat ilmu mulai mengemuka, ketika ilmu pengetahauan dan teknologi (iptek) mengalami kemajuan yang sangat pesat. Ketika itu muncul semacam kekhawatiran dari para ilmuwan dan filosof, termasuk juga dari kalangan agamawan, bahwa kemajuan ilmu pengetahuan dan teknologi dapat mengancam eksistensi umat manusia bahkan alam berikut isinya. ${ }^{1}$

Jika melihat makna filsafat secara mendalam maka tentu muncul asumsi bahwa filsafat adalah berpikir yang bebas dan radikal. Bebas dalam hal ini artinya bahwa tidak ada yang menghalangi pikiran bekerja, dan kerja pikiran ada di otak. Oleh karena tidak ada satu kekuatanpun, baik Raja maupun penguasa Negara manapun yang bisa mengahalangi seseorang berpikir, apalagi mengatur atau menyeragamkannya, sepanjang orang itu memiliki akal dan jiwa yang sehat, sehingga meskipun orang itu di penjara, tetap saja pikirannya dapat bekerja. ${ }^{2}$

Melihat pengertian filsafat di atas, dapat dikatan bahwa berpikir adalah jalan filsafat, dan hanya dimiliki oleh orang yang bijak seperti jalannya para "ahli hikmah" (bukama).

Manusia dan binatang adalah dua mahluk yang bernyawa dan sama-sama mahluk ciptaan Tuhan yang ada di dunia ini. Jika tujuan hidup binatang untuk beradaptasi dengan alam, maka tujuan hidup manusia adalah memanusiakan (bumanizing) dunia melalui proses transformasi dan pengetahuan. Binatang tidak mempunyai kesadaran historis (bistorical sense), tidak punya pilihan dan nilai dalam hidupnya, sedangkan manusia mempunyai kesadaran sejarah dan nilai. Manusia mempunyai sense of project sebagai lawan dari rutinitas instingstif-nya (instingtive routines) binatang. ${ }^{3}$ Oleh karena itu manusia membutuhkan pengetahuan, dan untuk mendukung pengetahuannya tentu dengan melalui pendidikan.

\footnotetext{
${ }^{1}$ Asmaji Muchtar, Dialektika Filsafat Ilmu, tth, tp, 1.

${ }^{2}$ Musa Asy'ari, Filsafat Islam; Sunnah Nabi Dalam Berpikir, (Yogyakarta: LESFI, 2010), 2.

${ }^{3}$ Paulo Freire, Politik Pendidikan Kebudayaan: Kekuasaan dan Pembebasan, (Yogyakarta: Pustaka Pelajar, $2002), 83$.
} 
Manusia sebagai mahluk pengemban amanah kekhalifahan mempunyai potensi yang luar biasa besarnya sehingga dapat mendayagunakan alam dan sesama manusia dalam membangun peradaban. Kemajuan sebuah bangsa pada umumnya ditentukan oleh bangsa itu dalam mendayagunakan sumber manusia melalui pergumulannya mengembangkan ilmu pengetahuan. ${ }^{4}$

Kaitannya dengan hal ini, maka setiap individu sangat perlu untuk mendapatkan pendidikan. Ditinjau dari konteks teoritis, pendidikan merupakan sarana untuk menyalurkan pengetahuan, Pendidikan adalah hak anak-anak, pendidikan adalah hak kaum perempuan. Seluruh dunia telah sepakat bahwa pendidikan harus mendapatkan tempat yang setinggi-tingginya dalam setiap programprogram pembangunan di Negara manapun. Deklarasi universal tentang hak asasi pada tahun 1948 telah menempatkan hak memperoleh pendidikan menjadi salah satu prioritas. Hak memperoleh pendidikan adalah bagian dari hak asasi manusia yang di atur oleh undang-undang sebagai berikut:

Setiap orang berhak mengembangkan diri melalui pemenuhan kebutuhan dasarnya, berhak mendapat pendidikan dan memperoleh manfaat dari ilmu pengetahuan dan teknologi, seni dan budaya, demi meningkatkan kualitas hidupnya dan demi kesejahteraan umat manusia. ${ }^{5}$

Pendidikan adalah sebuah hak asasi sekaligus sebuah sarana untuk merealisasikan hak-hak asasi manusia lainnya. Sebagai hak perempuan, pendidikan adalah sarana utama dimana orang dewasa dan terutama anak-anak yang dimarjinalkan secara ekonomi dan sosial dapat mengangkat diri mereka keluar dari kemiskinan dan memperoleh cara untuk terlibat dalam komunitas mereka. Pendidikan memainkan sebuah peranan penting untuk memberdayakan perempuan, melindungi anak-anak dari eksploitasi kerja dan seksual yang berbahaya. ${ }^{6}$

Hak atas pendidikan itu sendiri adalah hak asasi manusia dan merupakan suatu sarana yang mutlak diperlukan untuk mewujudkan hak-hak lain. Penyelesaian suatu program pendidikan yang sudah ditetapkan dengan memuaskan merupakan pra-syarat yang sangat penting untuk akses mendapatkan pekerjaan, sehingga

${ }^{4}$ A. Malik Fadjar, Reorientasi Pendidikan Islam, (Jakarta : Fajar Dunia, 1999), 43.

${ }^{5}$ Pasal 28 ayat (1) Undang-Undang Dasar 1945.

${ }^{6}$ Hak Tentang Pelaksanaan Atas Hak Pendidikan yang Disarikan dari Pelatihan HAM Kerjasama FH UPN “Veteran” JATIM Dengan KOMNASHAM RI. 
pendidikan dilihat sebagai gerbang menuju keberhasilan. Kesejahteraan yang kuat dapat dilihat antara hak atas pendidikan dan pengembangan penghormatan martabat manusia.

Setiap orang berhak atas perlindungan bagi pengembangan pribadinya, untuk memperoleh pendidikan, mencerdaskan dirinya, dan meningkatkan kualitas hidupnya agar menjadi manusia yang beriman, bertaqwa, bertanggung jawab, berakhlak mulia, bahagia, dan sejahtera sesuai dengan hak asasi manusia. ${ }^{8}$ Saat ini pendidikan merupakan sebuah upaya bangsa bukan saja sekedar untuk mencerdaskan anak didik, tetapi juga menenamkan rasa cinta terhadap tanah air, semangat membela dan berkorban untuk Negara dan bangsa. ${ }^{9}$

Sebagai bangsa dan negara besar yang ingin meningkatkan eksistensinya, Bangsa Indonesai selalu berupaya mencari solusi terhadap berbagai persoalan yang dihadapinya melalui perbaikan sistem politik, ekonomi, sosial budaya, maupun pendidikan.

Saat ini pendidikan di Indonesia menjadi suatu masalah yang sangat memprihatinkan, karena tidak semua anak-anak bangsa Indonesia yang bisa mendapatkan pendidikan. Banyak sekali anak-anak yang tidak mampu sekolah karena biaya sekolah yang tinggi, sehingga banyak anak yang tidak sekolah dengan alasan tersebut. Selain alasan itu juga, ada masalah lain yaitu adanya ketidak merataan pendidikan di Indonesia dan yang paling menonjol adalah ketidak merataan standar sarana dan prasarana sekolah yang memamdai.

Apa yang hendak dikemukakan dalam tulisan ini merupakan salah satu upaya memecahkan berbagai persoalan dalam upaya pemerataan pendidikan terutama pemerataan pendidikan bagi lapisan masyarakat, baik masyarakat yang tinggal di daerah-daerah terpencil, masyarakat primitif, maupun masyarakat yang masif dan kurang mengenyam pendidikan.

Berdasarkan urain singkat di atas, akan di bahas dalam tulisan ini sebagai berikut: Pendidikan sebagai karakter bangsa, selanjutnya yaitu bagaimana hak

\footnotetext{
${ }^{7}$ Rhona K.M. Smith, Njäl Host Melingen, dkk, Hukum Hak Asasi Manusia, oleh Pusat Studi Hak Asasi Manusia Universitas Islam Indonesia dengan Norwegian Centre for Human Rights (NCHR) University of Oslo, Norway (Yogyakarta : PUSHAM-UII, 2005), 131.

${ }^{8}$ Undang-undang No. 39 tahun 1999.

${ }^{9}$ Amien Rais, Agenda Mendesak Bangsa Selamatkan Indonesia (Yogyakarta : PPSK Press, 2008), 211.
} 
mendapatkan pendidikan ditinjau dari pandangan epistemologi, dan aksiologi filsafat ilmu.

\section{Metode dan Pendekatan}

Tidaklah keliru bila menganggap bahwa metode dan pendekatan (approach) itu kedua-duanya berbeda. Tetapi jika dikaji lebih mendalam, ternyata perbedaan keduanya memang sangatlah tipis, metode merupakan cara mengerjakan sesuatu (a way of doing something). Sementara pendekatan adalah cara memperlakukan sesuatu (a way of dealing with something). ${ }^{10}$ Perbedaan antara keduanya hanya terletak pada perlakuan atas objek. Metode cendrung menganggap sebuah objek sebagai entitas pasif. Sedangkan pendekatan cendrung menganggap sebuah objek sebagai sesuai yang aktif. Ketika seseorang akan memperlakukan, katakanlah, seekor ayam sebagai objek yang aktif maka ia berarti sedang melakukan pendekatan terhadap ayam. Sementara ketika ia memperlakukan perawatan terhadapnya, ayam dianggap sebagai benda pasif, maka sesungguhnya ia sedang melakukan metode perawatan ayam. Ketika seorang ingin mengkaji tentang hak mendapatkan pendidikan dan menganggapnya sebagai sebuah entitas yang aktif dan dinamis, maka sesungguhnya ia sedang melakukan pendekatan atas kajiannya. Namun bila ia memperlakukan dan memandang hak mendapatkan pendidikan itu sebagai suatu yang statis, maka ia sedang menggunakan suatu metode terhadap kajiannya itu.

Tulisan ini ingin memperlakukan pendidikan sebagai sebuah perubahan yang dinamis bagi setiap individu. Oleh karena itu, tulisan singakat ini menawarkan sebuah pendekatan filsafat pendidikan Islam khususnya dalam efistemologi dan aksiologi ilmu, atas hak mendapatkan pendidikan bagi setiap warga negara. Namun sebelum membahas lebih jauh alangkah baiknya jika penulis mengungkapkan pendekatan ini, sebagai langkah dalam mencari kerangka analitik terhadap persoalan pendidikan kita.

\section{Pendidikan Sebagai Karakter Bangsa}

Sebagai awal dari pembahasan ini, penulis melihat bahwa menanamkan pendidikan kepada bangsa Indonesia adalah berarti berupaya memberikan sikap dan

10 Muhyar Fanani, Metode Studi Islam; Aplikasi Sosiologi Pengetabuan Sebagai Cara Pandang, Cet. II, (Yogyakarta: Pustaka Pelajara, 2010), xxiii. 
nilai-nilai pengetahuan yang kuat untuk menjadi masyarakat dan bangsa yang berperadaban serta berkarakter.

Kaitannya dengan ini, maka pendidikan ádalah usaha sadar dan terencana untuk mewujudkan suasana belajar dan proses pembelajaran agar peserta didik secara aktif mengembangkan potensi dirinya untuk memiliki kekuatan spiritual keagamaan, pengendalian diri, kepribadian, kecerdasan, akhlak mulia serta keterampilan yang diperlukan dirinya, masyarakat, bangsa dan Negara. ${ }^{11}$

Dalam UU sisdiknas 2003 pasal 1 ayat (1) menyatakan pendidikan Nasional berdasarkan Pancasila dan Undang-undang Dasar Negara Republik Indonesia Tahun 1945 yang berakar pada nilai-nilai agama, kebudayaan nasional dan tanggap terhadap tuntutan perubahan zaman. ${ }^{12}$

Dengan landasan pendidikan di atas, berarti memberikan interpretasi dan pemaknaan bahwa pendidikan berupaya menanamkan nilai-nilai keagamaan, cultural dan budaya terhadap masyarakat Indonesia secara menyeluruh. Sejalan dengan hal tersebut, hak mendapatkan pendidikan harus menjadi pemahaman yang konprehensif terhadap bangsa Indonesia, agar dapat dibangun sikap pendidikan yang bumanizing dan memanusiakan.

Disamping itu, karakter bangsa yang dibangun dalam pendidikan Indonesia tentunya dapat memberikan nilai positif untuk terus dapat berkembang sesuai dengan perubahan zaman. Mengutip pandangan Al-Gazali menyebutkan potensi manusia itu ada empat komponen yang merupakan sistem kepribadian manusia yaitu: ruh, kalbu, akal dan nafsu. Hampir senada dengan al-Gazali, Sigmond Freud membagi komponen sistem kepribadian manusia meliputi: super ego, ego dan ide.

Kaitannya adalah manusia sebetulnya memiliki kemampuan intern yang harus terus diasah, diaplikasikan dan dituangkan dalam bentuk pelaksanaan pendidikan sebagi bentuk wujud salah satu potensi yakni berpikir. Selain itu, pengembengan jatidiri manusia dan karakter akan dapat terlaksana dengan semangat belajar atau ilmu-ilmu yang dipelajari. Sehingga dengan itu, sumberdaya manusia dan pembentekuan karakter manusia yang berilmu, berbudi, bermartabat, dan memiliki wawasan pengetahuan yang luas dan memadai akan dapat terwujud. Karenanya, Islam

${ }^{11}$ Fathul Jannah, Pendidikan Islam Dalam Sistem Pendidikan Nasional, Vol 13. No 2. Desember 2013, 163.

12 UU Sisdiknas 2013 pasal 1 ayat (1). 
juga mengajrakan untuk terus berusaha dengan maksimal agar apa yang dicita-citakan akan dapat diraih.

Terlepas dari kenyataan ini, peranan pendidikan dalam pembangunan dan karakter sebuah bangsa menjadi salah satu dasar yang perlu menjadi perhatian serius dari seluruh pihak, bukan saja dari aparatur pendidikan sebagai pemangku kebijakan, namun secara lebih luas yakni semua lapisan, baik masyarakat, lembaga pendidikan dan praktisi pendidikan yang juga ikut andil dan bertanggung jawab dalam mewujudkan cita-cita dari satu bangsa untuk memiliki sumber daya manusia yang memadai. Sejalan dengan ini, oleh William S. Platt pernah menyatakan bahwa "to ward strategis of education", pendidikan memang sangat penting untuk terus dilaksanakan agar pembangunan sumber daya manusia menjadi terlaksana, terutama pada bangsa Indonesia.

Lebih jauh lagi, peranan manusia dalam aspek pembangunan digambarkan bahwa manusia sebagai produsen yakni dapat berperan aktif sebagai seorang distrubutor yang siap pakai dalam setiap kebutuhan memproduksi dan mendistribusikan berbagai pengetahuan yang dimiliki. Sejauh ini, manusia harusnya mengenal diri bahwa, setiap diri mampu mengembangkan kemampuan-kemampuan yang dimiliki untuk kepentingan orang lain terlebih dalam satu bangsa, masyarakat yang majemuk seperti Indonesia.

Peran aktif setiap individu dapat digambarkan dalam setiap langkah dan peranannya sebagai seorang yang berpikir. Selaras dengan apa yang disampaikn KH. Hasyim Muzadi dalam ungkapannya “ jika akal yang kosong maka isilah dengan ilmu pengetahuan, dan bila hati yang kosong isilah dengan zikir. Pikir dan zikir akan membentuk manusia ulul al-Bab". Sebagaimana yang terkandung dalam ajaran-jaran Islam. Ungkapan ini menurut hemat penulis bertujuan menunjukkan makna yang mendalam terhadap eksistensi dan kebradaan manusia di muka bumi, yakni tidak lain adalah individu yang mampu menghubungkan sikap batiniah dan ruhiahnya kedalam pelaksanaan kehidupan yang memberi manfaat baik diri dan untuk oranglain.

\section{Tinjauan Epistemologi Hak Mendapatkan Pendidikan}

Epistemologi adalah teori atau ilmu pengetahuan tentang metode dan dasardasar pengetahuan, khususnya yang berhubungan dengan batas-batas pengetahuan 
dan validitas atau sah berlakunya pengetahuan itu, ${ }^{13}$ secara sederhana dapat diartikan sebagai landasan dalam mencapai suatu pengetahuan.

Kaitannya dengan hak mendapatkan pendidikan ini, maka landasan yang utama menurut ajaran Islam adalah Qur'an (azzikr). AL-Qur'an sebagai konstitusi dan sumber normatif filsafat pendidikan Islam yang pertama ini merupakan budan, atau petunjuk bagi kehidupan manusia meskipun al-Qur'an bukan kitab pendidikan, tetapi sejatinya didalam ayat-ayatnya terkandung istilah-istilah berkenaan dengan pendidikan. Misalnya 5 ayat pertama dalam surat al-Alaq dengan jelas mengandung unsur pendidikan. Di dalam ayat-ayat ini tertera istilah iqra (bacalah), allama (mengajarkan), al-Qalam (pena/alat tulis), dan ya'lam (mengetahui). Kalau dipahami secara lebih mendalam, istilah-istilah seperti baca, mengajar, pena, dan mengetahui erat sekali hubungannya dengan pendidikan. ${ }^{14}$

Allah dalam konsep filsafat pendidikan Islam merupakan "pendidik yang maha agung", yang bukan hanya mendidik manusia melainkan juga makhluk seluruhnya. Oleh karena itu Al-Qur'an tentang pendidikan bersifat menyeluruh dan terpadu, mengandung perkembangan dan perubahan. Menyeluruh dalam arti meliputi wujud keseluruhannya terpadu artinya memadukan antara material dan spiritual, antara dunia dan akhirat. Filsafat al-Qur'an mengandung perkembangan dan perubahan maksudnya mengajak manusia untuk meningkat kearah yang lebih baik dan sempurna. ${ }^{15}$

Selain itu juga, salah satu misi sentral Nabi Muhammad SAW adalah meningkatan kualitas SDM yang utuh tidak hanya secara jasmaniah tetapi juga batiniah atau rohaniah. Nabi Muhammad SAW diutus untuk mengembangkan kualitas kehidupan manusia, mensucikan moral, etika, akhlak dan membekali mereka dengan bekal-bekal yang diperlukan dalam menjalani kehidupan dunia dan akhirat. ${ }^{16}$

Dengan demikian dapat dikatakan bahwa hak mendapatkan pendidikan bagi setiap individu harus menyuluruh dan efesien sesuai dengan tujuan dan orientasi pendidikan Islam yaitu mencerdaskan setiap individu dengan memegang nilai-nilai

${ }^{13}$ Amsal Baktiar,..Filsafat Ilmu, (Jakarta: Raja Grafindo Persada,2004), 145

14 Abuddin Nata, Manajemen Pendidikan: Mengatasi Kelemahan Pendidikan Islam di Indonesia, (Jakarta: Pranada Media Group, 2003), 228.

${ }^{15}$ Toto Suharto, filsafat Pendidikan Islam, Cet, Kedua, (Yogyakarta: Ar-Ruzz Media, 2013), 120.

16 Azyumardi Azra, Pendidikan Islam: Tradisi dan Modernisasi di Tengah Tantangan Melenium III, (Jakarta: Kencana Pranada Media Group, Cet 1 April, 2012), 61. 
ilabiah (Qur'ani) dan sekaligus sebagai pedoman dalam membentuk genarasi emas, yang kreatif, inovatif, kompetetif, dan berdedikasi dalam setiap langkah dan sikap (insan kamil). Selanjutnya, sunnah atau ajaran Rasulullah SAW sebagai sumber normatif kedua, senantiasa memberikan perhatian yang besar terhadap masalah pendidikan. Salah satu konsep pendidikan yang ditawarkan Rasulullah adalah konsep pendidikan tanpa batas (no limits education) baik tanpa batas dalam arti ruang atau tempat maupun tanpa batas dalam arti waktu yang sering disebut pendidikan sepanjang hayat (long life education). Inti konsep pendidikan melalui sunnahnya mempunyai dua fungsi yaitu:

1. Menjelaskan sitem pendidikan Islam yang terdapat di dalam al-Qur'an dan menerangkan hal-hal yang tidak termaktub didalamnya.

2. menyimpulkan metode pendidikan dari kehidupan Rasulullah bersama para sahabatnya perlakuan terhadap anak didik dan bagaimana Rasulullah menanamkan keimanan ke dalam jiwa mereka. ${ }^{17}$

Selain itu hak mendapatkan pendidikan juga tercantum dalam peraturan perundang-undangan baik nasional maupun internasional. Berikut ini penulis paparkan peraturan perundangan hak dalam mendapatkan pendidikan:

Setiap orang berhak mengembangkan diri melalui pemenuhan kebutuhan dasarnya, berhak mendapat pendidikan dan memperoleh manfaat dari ilmu pengetahuan dan teknologi, seni dan budaya, demi meningkatkan kualitas hidupnya dan demi kesejahteraan umat manusia. ${ }^{18}$

Setiap orang berhak atas perlindungan bagi pengembangan pribadinya, untuk memperoleh pendidikan, mencerdaskan dirinya, dan meningkatkan kualitas hidupnya agar menjadi manusia yang beriman, bertaqwa, bertanggung jawab, berakhlak mulia, bahagia, dan sejahtera sesuai dengan hak asasi manusia. ${ }^{19}$

\footnotetext{
${ }^{17}$ Ibid., 121.

${ }^{18}$ Pasal 28 C ayat (1) Bab XA Tentang Hak Asasi Manusia Undang-undang Dasar 1945.

${ }^{19}$ Undang-undang No. 39 tahun 1999 Tentang Hak Asasi Manusia
} 
Tabel I.

Pasal 31 ayat $1-5$ Bab XIII

Tentang Pendidikan dan Kebudayaan, Undang-undang Dasar $1945^{20}$

\begin{tabular}{|c|l|}
\hline No. & Peraturan Perundang Undangan Hak Mendapatkan Pendidikan \\
\hline 1. & Setiap warga negara berhak mendapat pendidikan. \\
\hline 2. & $\begin{array}{l}\text { Setiap warga negara wajib mengikuti pendidikan dasar dan pemerintah wajib } \\
\text { membiayainya. }\end{array}$ \\
\hline 3. & $\begin{array}{l}\text { Pemerintah mengusahakan dan menyelenggarakan satu sistem pendidikan } \\
\text { nasional, yang meningkatkan keimanan dan ketakwaan serta ahlak mulia } \\
\text { dalam rangka mencerdaskan kehidupan bangsa, yang diatur dengan undang- } \\
\text { undang. }\end{array}$ \\
\hline 4. & $\begin{array}{l}\text { Negara memprioritaskan anggaran pendidikan sekurang-kurangnya dua puluh } \\
\text { persen dari anggaran pendapatan dan belanja negara serta dari anggaran } \\
\text { pendapatan dan belanja daerah untuk memenuhi kebutuhan penyelenggaraan } \\
\text { pendidikan nasional. }\end{array}$ \\
\hline 5. & $\begin{array}{l}\text { Pemerintah memajukan ilmu pengetahuan dan teknologi dengan menunjang } \\
\text { tinggi nilai-nilai agama dan persatuan bangsa untuk kemajuan peradaban serta } \\
\text { kesejahteraan umat manusia. }\end{array}$ \\
\hline
\end{tabular}

\section{Tinjauan Aksiologi Dalam Hak Mendapatkan Pendidikan}

Aksiologi yaitu teori nilai yang berkaitan dengan kegunaan dari pengetahuan yang diperoleh ${ }^{21}$. Terdapat 2 hal yang menjadi aspek aksiologi dari hak mendapatkan pendidikan yang dibahas pada tulisan ini. Pertama, hak warga negara memperoleh pendidikan. Kedua, kewajiban pemerintah dalam meyelenggarakan pendidikan.

\footnotetext{
${ }^{20}$ Pasal 31 ayat 1-5 Bab XIIITentang Pendidikan dan Kebudayaan,Undang-undang Dasar 1945.

${ }^{21}$ Jujuj S Suria Sumantri, Filsafat Ilimu Sebuab Pengantar Populer, (Jakarta : Sinar Harapan, 2001)
} 


\section{Hak Warga Negara Mendapatkan Pendidikan}

Dalam UUD pasal 31 ayat 1 dan 2 tertulis bahwa setiap warga negara berhak mendapat pendidikan, wajib mengikuti pendidikan dasar dan pemerintah wajib membiayainya, Negara juga mempriorotaskan anggaran pendidikan sekurangkurangnya 20 persen dari APBN dan APBD. Pertanyaanya, adalah sudahkah semua anak bangsa mendapatkan haknya? Melihat fakta saat ini, di Indonesia setiap tahunnya lebih dari 1,5 juta anak sekolah tidak melanjutkan pendidikan ke jenjang yang lebih tinggi.

Sebuah pertanyaan pahit begitu jelas dihadapan kita. Mengapa ketentuan yang demikian penting buat kemajuan pendidikan bangsa diabaikan oleh pemerintah?. Secara konsisten secara 4 kali berturut-turut di era Yudhoyono. Pemerintahan telah melanggar konstitusi. Bahkan dalam APBN 2008 anggaran pendidikan hanya 69,4 triliun rupiah dari jumlah seluruh APBN yang mencapai 854,7 triliun rupiah, jadi hanya 8 sekian persen saja. ${ }^{22}$

Kita bisa melihat saat ini betapa susahnya rakyat ingin sekolah, banyak masyarakat yang tidak mampu menyekolahkan anaknya karena faktor ekonomi yang tidak mendukung. Pendidikan yang seharusnya di dapatkan dengan mudah karena sudah dijamin oleh undang-undang, tapi pada kenyataannya pendidikan Indonesia saat ini sangat memprihatinkan karena pendidikan menjadi harga yang sangat mahal yang harus dibayar oleh rakyat.

Selain itu, pendidikan di Indonesia juga terjadi kesenjangan antara daerah perkotaan dengan daerah pedesaan. Semakin terpencil suatu daerah maka semakin minim perhatian pemerintah terhadap pendidikan. Oleh karena itu dapat disimpulkan bahwa hak warga dalam mendapatkan pendidikan di Indonesia masih terjadi kesenjangan yang sangat besar.

\section{Kewajiban Pemerintah/Negara Menyelenggarakan dan Menjamin Pendidikan}

Penyelenggaraan pendidikan dasar merupakan tanggung jawab bersama antara Pemerintah, Pemerintah Daerah, dan masyarakat. Pendanaan pendidikan menjadi tanggung jawab bersama antara Pemerintah, Pemerintah Daerah dan

22Ibid., 194 
masyarakat. Dalam hal ini sumber pendanaan pendidikan dari pemerintah meliputi Anggaran Pendapatan dan Belanja Negara (APBN) dan Anggaran Pendapatan dan Belanja Daerah (APBD), dan sumber pendanaan pendidikan dari masyarakat mencakup antara lain sumbangan pendidikan, hibah, wakaf, zakat, pembayaran nazar, pinjaman, sumbangan perusahaan, keringanan, dan penghapusan pajak untuk pendidikan, dan lain-lain penerimaan yang sah. ${ }^{23}$

Pada dasarnya, pendidikan adalah unsur terpenting di dalam sebuah negara. Karena dari pendidikan, lahir sumber daya manusia yang handal. Oleh karena itu jika pendidikan di dalam suatu negara tidak dikelola dengan baik bahkan diabaikan, maka sudah dapat dipastikan anak bangsa yang lahir sebagai penerus untuk membangun negara akan menjadi seorang yang tak berdaya tergerus oleh jaman, dan akan berdampak pada kelangsungan hidup suatu negara. Hanya saja, pendidikan yang diimpikan oleh semua kalangan masyarakat hanyalah menjadi mimpi karena begitu besar dan kompleks permasalahan yang terjadi di dalam dunia pendidikan Indonesia. Salah satunya adalah masih banyak anak Indonesia yang tidak bisa menikmati atau melanjutkan pendidikannya. Jumlah anak putus sekolah dan berpendidikan rendah di Indonesia masih tinggi.

Inilah kenyataan yang ada di Indonesia, kalau kita lihat dari realita yang ada saat ini sungguh sangat miris, karena walaupun sudah ada undang-undang yang mengatur tentang hak asasi manusia khususnya hak mendapatkan pendidikan, tetapi undang-undang tersebut sampai sekarang belum bisa dilaksanakan secara maksimal saat ini. Bisa dilihat banyak sekali sekolah yang roboh dan tidak layak huni, angka putus sekolah juga semakin meningkat, dan biaya pendidikan juga semakin tinggi.

\section{Catatan Akhir}

Berdasarkan uraian di atas, maka hak mendapatkan pendidikan telah diterangkan di dalam al-Qur'an bahwa Allah adalah sebagai pendidik seluruh makhluknya. Disamping itu juga, al-Qur'an telah menggambarkan pendidikan sebagai petunjuk bagi seluruh proses kehidupan manusia. Hal tersebut terbukti dari sebagian

${ }^{23}$ Emmanuel Sujadmoko, Hak warga Negara Dalam Memperoleh Pendidikan, Jurnal Konsitusi Vol. 7 Mahkamah Konstitusi Republik Indonesia, 2010 
ayat yang terdapat dalam surat al-Alaq yaitu iqra (bacalah), allama (mengajarkan), alQalam (pena, alat tulis), dan ya'lam (mengetahui).

Selain itu juga, Rasulullah SAW dalam salah satu misi sentralnya yaitu meningkatkan sumber daya manusia (SDM) yang tidak hanya dalam ranah jasmaniah saja namun lebih daripada itu, aspek rohaniah pun tetap harus terpenuhi. Hal ini membuktikan bahwa hak mendapatkan pendidikan harus menyeluruh, dan pendidikan tersebut tidak memiliki batas (no limits education).

Disamping itu, hak mendapatkan pendidikan juga tercantum dalam peraturan perundang-undangan baik nasional maupun internasional yang dimana pada intinya adalah hak tersebut harus didapatkan oleh setiap warga Negara untuk mengembangkan potensi yang dimiliki sehingga dapat meningkatkan kualitas pengetahuan dan kesejahteraan hidupnya.

Melihat betapa pentingnya hak mendapatkan pendidikan, maka pemerintah wajib memberikan anggaran terhadap setiap warga Negara sesuai dengan APBN dan APBD yang sudah ditetapkan untuk biaya pendidikan baik proses dan operasionalnya. Sehingga, kewajiban atas hak mendapatkan pendidikan ini tentu dapat dijalankan dengan maksimal, apabila pemerintah pusat, pemerintah daerah dan masyarakat bersinergi yakni dengan tujuan yang sama yaitu mencerdaskan kehidupan warga Negara meningkatkan sumber daya manusia melalui pendidikan yang menyeluruh.

\section{Daftar Pustaka}

Asy'ari, Musa. 2010, Filsafat Islam; Sunnah Nabi Dalam Berpikir, (Yogyakarta: LESFI).

Azra, Azyumardi. 2012, Pendidikan Islam: Tradisi dan Modernisasi di Tengah Tantangan Melenium III, Jakarta: Kencana Pranada Media Group, cet 1 April).

Baktiar, Amsal. 2004, Filsafat Ilmu, (Jakarta: Raja Grafindo Persada).

Emmanuel Sujadmoko, Hak warga Negara Dalam Memperoleh Pendidikan, Jurnal Konsitusi Vol. 7 Mahkamah Konstitusi Republik Indonesia, 2010.

Freire, Paulo. 2002, Politik Pendidikan Kebudayaan; Kekuasaan dan Pembebasan,(Yogyakarta: Pustaka Pelajar).

Malik, Fadjar, A. 1999, Reorientasi Pendidikan Islam (Jakarta : Fajar Dunia). 
Muchtar, Asmaji, Dialektika Filsafat Ilmu, tth, tp.

Nata, Abuddin. 2003, Manajemen Pendidikan: Mengatasi Kelemahan Pendidikan Islam di Indonesia (Jakarta: Pranada Media Group).

Pasal 28 Ayat (1) Undang-Undang Dasar 1945.

Pasal 28 C ayat (1) Bab XA Tentang Hak Asasi Manusia Undang-undang Dasar 1945.

Pasal 31 ayat 1 - 5, Bab XIII Tentang Pendidikan dan Kebudayaan, Undang-undang Dasar 1945.

Rhona K.M. Smith, Njäl Hostmelingen, dkk, Hukum Hak Asasi Manusia, oleh Pusat Studi Hak Asasi Manusia Universitas Islam Indonesia dengan Norwegian Centre for Human Rights (NCHR) University of Oslo, Norway (Yogyakarta: PUSHAM-UII, 2005).

Rais, Amien. 2008, Agenda Mendesak Bangsa Selamatkan Indonesia, (Yogyakarta: PPSK Press).

Suharto, Toto. 2013, Filsafat Pendidikan Islam, Cet, Kedua, (Yogyakarta: Ar-Ruzz Media).

Undang-undang No. 39 tahun 1999 Tentang Hak Asasi Manusia. 